\title{
The Effect of Collaborative Writing on Iranian EFL Learners' Task Achievement in Writing and Their Perception
}

Hossein khodabakhshzadeh, Farideh Samadi*

English Department, Islamic Azad University, Torbat-e Heydarieh Branch, Iran

Corresponding Author: Farideh Samadi, E-mail: farideh4oct@gmail.com

\section{ARTICLE INFO}

\section{Article history}

Received: August 13, 2017

Accepted: October 22, 2017

Published: January 05, 2018

Volume: 7 Issue: 1

Advance access: December 2017

Conflicts of interest: None Funding: None

\begin{abstract}
Collaborative writing has gained interest in the last decade; however, as stated by Shin, Lidster and Sabraw (2016) more research is required to delve into various aspects of this multifarious class activity. This true experimental research examined the effect of writing collaboratively on task achievement of Iranian EFL learners in writing. Oxford Placement Test was given to 60 language learners in the city of Kashmar, Iran, as the test of homogeneity. Considering +/-1 standard deviation of the mean score, 40 learners were chosen to pursue the purpose of the study. These learners formed an experimental group and a control group with 20 participants in each. Collaborative writing was implemented in the experimental group and individual writing was used in the comparison group. The participants in the experimental group were later interviewed and their perception toward collaborative writing was investigated. The findings of the study through t-test revealed that the experimental group participants outperformed the ones in the control group in terms of task achievement. In addition, the results of the semi-structured interview through thematic analysis revealed that most participants found collaborative writing effective in terms of motivation, peer feedback, comprehensive view over the topic, changing ineffective writing habits, and vocabulary learning; though peer authority and teacher authority were considered as inhibiting factors. Pedagogical implications are discussed.
\end{abstract}

Key words: Collaborative Writing, Task Achievement, Learners' Perception

\section{INTRODUCTION}

Recent research in second language acquisition (SLA) has witnessed a shift in attention to learners (Kumaravadivelu, 2006), which has, in turn, resulted in emergence of learner-centered approaches to language learning. In terms of writing, it is believed that listening to learners' voice and utilizing their collaborative abilities can not only affect the outcome of writing course, but also increase the quality of writing processes (Storch, 2005). Gopee and Deane (2013) posited that a suitable way to reduce the pressure of writing classes is to delve into learners' perception about writing. Choi (2016) asserted that students' perception of writing processes can inform the teachers about the strategies they use in writing. Gordon (2008) also concluded that writing habits of the learners affects the quality of their writing which he investigated by interviewing learners and studying their perception. In addition, Storch (2005) asserted that collaborative writing can have more effect than individual writing on academic texts in terms of quality of the produced text. Elsewhere, Storch and Wigglesworth (2010) posited that collaborative writing provides language learners with a variety of corrective feedback types, i.e., direct, indirect, etc. Therefore, they emphasized the role of collaboration in writing classes.

These studies motivated the researcher to have an indepth look at learners' perception about writing and also the effect of collaborative writing in EFL context of Iran; believing that research in Iran has mostly been concerned with products of writing classes and not the processes. Thus, this study sought to find an approach to enhance Iranian EFL learners' task achievement in writing which is defined by Verhelst, Van Avermaet, Takala, Figueras, and North (2009) as fully satisfying the requirements of the writing task by presenting fully developed responses. To this end, the researcher investigated the effect of collaborative writing on task achievement of Iranian EFL learners and delved into the learners' perception about collaborative writing processes; believing that the findings of the study can enhance the outcome of writing classes and help to avoid hampering issues as perceived by the learners. It can aid language teachers to decide whether or not to use collaborative tasks in their classes or to make use of individual tasks. In addition, teachers will gain more insight about how learners fill in the class and about types of classroom activities by considering the results of the study. 


\section{Problem Statement}

Research on writing in the EFL context of Iran is sparse. One of the issues which requires more attention is EFL writers' task achievement. Although it is one of the rubrics of high standard tests such as the IELTS, it has often been disregarded by researchers which may be due to its subjective nature. Failing to fulfil task achievement criteria in the writing exams as stated in the Verhelst et al. (2009) results in reduction of test takers scores and, in turn, losing the desired position in higher educational systems. As a result, this requires instant attention. Moreover, not only is research on task achievement scant, but also its interactions with collaborative writing are not fully understood. Due to insufficient research in this area, language learners may be losing opportunities to learn task achievement which urges the need for this study.

Finally, insufficient attention is paid to learners' perception regarding the writing skill in Iran (Rahimi \& Ghannadzadeh, 2010), and dynamics of collaboration in writing classes in Iran seem to have remained untouched. Thus the major problems to be investigated in this study are learners' perception about writing processes and the effect of collaborative writing on writing.

\section{Research Questions}

1. What is the effect of collaborative writing on Iranian EFL learners' task achievement in writing?

2. What is the perception of Iranian EFL learners about implementing collaborative writing in classes?

\section{REVIEW OF THE LITERATURE}

The idea for collaboration in language classes and students' perception both became popular in 1970s and 1980s. Vygotsky (1978) constructivist view and Lazanov's "whole person" which urges considering language learners' affection and perception of the learning environments (Lazanov, 2004) were to main theories based on which numerous research has been conducted. Crewsell (2009) stated that meaning cannot always be accepted as it is observed and has associations with how it is formed in the mind of the individuals. As stated by him, Vygotsky's concept of "social constructivism" also implies that meaning is formed through social interactions. This idea became to underlying assumption of communicative methods such as communicative language teaching (CLT) (Larsen-freeman \& Anderson, 2013). In addition to CLT, learner-based approached to learning such as problem-based learning all favor collaboration and look at processes of collaboration (Savery, 2006). A significant portion of these processes is looking at learners' perception. Indeed, the very firs proof on collaborative processes in project-based and problem-based learning environments came from learners; positive view, as, even in cases they scores were reduced in fina achievement tests, they considered themselves real learners who have indulge the activity (Lee \& Kwan, 1997).

The above mentioned theoretical backgrounds support the idea that language learners' task achievement in writing can be affected by collaborative writing tasks. In order to do so, the researcher will have a look at the learners' perceptions about collaborative processes. Task achievement, has been define differently in the literature. More objective views about task achievement have defined it as being able to write a certain number of words in an allotted amount of time. The common European Framework (Verhelst et al., 2009) consider task achievement being able to write 250 words in 40 minutes in form of a 5 paragraph essay. Other sources such as Riazi (2015) question object view of such assessment systems with regard to TOEFL iBT test and consider writing more than mechanics of writing and linguistic features of the text, i.e., grammar, vocabulary. Stevenson (2016) posits that achieving the purpose of the writing task means considering 3 elements: purpose, action and use which will not be achieved by sole attention to linguistic features of the text. Task achievement in this study, as stated by Conner and Mbaye (2002) is defined as being able to consider Canal and Swain (1980) communicative model in writing, which, in turn, means considering how successful the writers use strategies to write. As the focus of this study is on task achievement In argumentative writing, qualitative scoring based on Conner and Mbaye (2002) was utilized to score the essays task achievement.

\section{Empirical Background}

Collaboration and learners' perception has been the subject of research in some studies in the last decade. This issue has been studied in detail by some scholars. A few of these studies are discussed in this section.

Alshehadeh (2011) designed a pretest/posttest study with 38 first-year students. He used the writing scale originally developed by Jacobs, Zinkgraf, Wormuth, Hartfiel and Hughey (1981) adopted from Hedgcock and Leftkowitz (1992). The focus of the model was on content, organization, grammar ad vocabulary. Each of these components were assessed on 4 bands, (excellent to poor) and were scored holistically. In addition, the students in the collaborative writing group were surveyed. The results indicated that, in general, collaborative group participants outperformed the individual participants, though the results varied from one item on the scale from another.

In a mixed-mode study, Nassaji and Tian (2010), investigated the effect of reconstruction cloze tasks and reconstruction editing tasks on learning phrasal verbs by lower intermediate ESL learners. The researchers also delved into the nature of interactions between the participants in collaborative groups. They used two cohorts of participants in form of two intact classes. Their interest was to find out how collaborative writing can contribute to gaining knowledge of the target verbs compared to individual writing. The findings of their study revealed that conducting the tasks in pairs resulted in more accuracy of task completion than doing them one by one. in terms of vocabulary learning, both types of tasks proved to be similar.

In another mixed-mode study, Mozaffari (2016) had a close look at pair work in writing classes and examined the nature of teacher-selected groups and student-selected groups in order to understand whether the students should select their partners in collaborative writing tasks. The data 
collected for this mixed-mode study was through recording audio which was later analyzed for 3 main categories, i.e., the quantity, type and resolution of language related episodes (LREs). In addition to that, patterns of dyadic interactions were sought. Furthermore, the study examined the texts produced using both quantitative and qualitative measures. The findings suggest that the groups assigned by teachers can produce more LRE's than groups assigned by the students, however, in terms of patterns of interaction no significant difference was found. In addition, the qualitative section of the study revealed off-task behavior among the members of pairs selected by the students. Finally, in terms of organization, grammar and vocabulary, the teacher-selected pairs outperformed student-selected pairs.

In a different quantitative study, Shin, Lidster and Sabraw (2016) did not believe that enough has been said about collaboration in writing classes. Thus, they aimed at understanding how L2 proficiency of partners affect their writing in terms of content accuracy in dictogloss task. The study was conducted in USA by making use of 38 participants in 4 intact classes, idea units were considered and coded to pursue the purpose of the study. it was found that idea units reproduction can be effective. In addition, paring low-level students with high-level students was beneficial for the low-level students

\section{METHOD}

\section{Theoretical Background}

The study is based on the constructivist view, as the theoretical basis for this research lies heavily upon the work of Vygotsky (1978). The key concept of his theory was the role of social interactions in learning; which is the underlying assumption of the communicative approach in L2 learning. Another very significant theory used in this study is Hirvela (1999) which posits that collaborative writing gives learners a boost and fosters learning as they can use peers for guidance. Her model was later expanded by Storch (2005) who recognized collaboration and pair work as a means to higher quality writing. These three theories were among the most significant theories used selected for this stud.

\section{Research Design}

This mixed-mode study had a look at the effect of collaborative writing on Iranian EFL learners' task achievement in writing (quantitative) and language learners' perception regarding collaborative writing (qualitative). The main independent variable in the study collaborative writing and the main dependent variable is task achievement of the learners in writing. Age and gender were among the confounding variables which were not dealt with in this study due to limited number of participants. However, all participants were adult EFL learners.

\section{Participants}

Sixty EFL learners who were studying at a language institute in the city of Kashmar, Iran participated in the study. All these learners were briefed on the purpose of the study and consent forms were collected in order to conduct an ethical research. OPT test was given to these participants to homogenize them based on their language proficienc . Considering +/_1 standard deviation of the mean score, 40 learners were selected who took an IELTS writing Task 2 as the pretest. Based on their score on the pretest the learners formed two homogeneous groups; i.e., an experimental group and a control group. Each group consisted of 20 participants. Table 1 reveals the demographics of the participants in these groups.

\section{Procedure}

The intervention phase of the study lasted over the period of two months for 16 sessions. The participants in both groups received explicit instruction on writing 5 paragraph argumentative essays. The topics used in the intervention were selected from IELTS Cambridge series and the procedure used to teach was opted from Cusack and McCarter (2007) and Oxford Essay Writing series. Through explicit instructions the following issues were taught to the participants in both groups:

a) Analyzing the topic

b) Writing an outline for the essay

c) Writing the 'hook' sentence in introduction.

d) Writing thesis statement

e) Developing ideas into paragraphs

f) Integration argumentation strategy

g) Pseudo-integration argumentation strategy

h) Refutation argumentation strategy

i) Coherence

j) Cohesion.

The participants in the experimental group went through collaborative writing sessions, as they were asked to write an essay in their group and to present it as their group's essay. The participants formed groups of 4. Explicit instruction was provided at the beginning of the task. Each topic was given to one group and they were asked analyze it individually and then collaboratively within the group and produce one essay in 40 minutes. The control group participants were simply asked to develop the given topics into paragraphs after the instruction was given in each session.

As for the qualitative section of the study, the participants in the experimental group were interviewed to find out about their perception with regard to collaborative writing processes.

\section{Data Analysis}

\section{Pre-study}

In the first phase of the study, OPT was administered to 60 English language learners. The test had 60 multiple-choice

Table 1. Demographics of the participants

\begin{tabular}{lcclll}
\hline Group & N & Age & Gender & Level & Religion \\
\hline Experimental & 20 & $18-29$ & Mixed & Intermediate & Islam \\
Control & 20 & $19-31$ & Mixed & Intermediate & Islam \\
\hline
\end{tabular}


items and by assigning 1 point to correct answers and 0 to the wrong answers, the test was scored. Then the statistics were done. Considering Table 2, the mean of the scores was $(M=57.21)$ and the standard deviation was $(S D=5.11)$.

In addition, normality test was done to ensure about normal distribution of the scores.

As can be seen in Table 3, ratios of skewness and kurtosis are within the range of $+/ 1.96$. Based on Strevens (2009), the assumption of normal distribution was met.

\section{The Pretest}

As two raters were asked to score participants' task achievement on writing, interrater reliability indices were checked for the pretest and the posttest.

As can be seen in Table 4, there was a significant agreement between the two raters who rated the subjects on task achievement in writing (pretest) $(\alpha=.941, \mathrm{p}=.001)$. Had a single rater rated them three times, the intra-rater reliability would have been $.888(\mathrm{p}=.001)$.

\section{Construct Validity; Pretest of Writing}

In order to probe the construct validity of the test, factor analysis was run.

As can be seen in Table 5, assumption of sampling adequacy was met. As displayed in Table 5 the KMO index of .811 was higher than the acceptable level of .50 .

The Bartlett's test was significant $\left(\chi^{2}(10)=552.311\right.$, $\mathrm{p}=.000$ ) indicating that there was not too high or too low correlations among all variables.

\section{Reliability of the Posttest}

As for the posttest, 2 raters were asked to score the papers. There was a significant agreement between the three raters who rated the subjects in terms of task achievement $(\alpha=.912$,

Table 2. Descriptive statistics, Oxford placement test

\begin{tabular}{lcccc}
\hline & N & Mean & $\begin{array}{c}\text { Standard } \\
\text { deviation }\end{array}$ & Variance \\
\hline $\begin{array}{l}\text { Oxford placement } \\
\text { test (Grammar }\end{array}$ & 60 & 57.21 & 5.11 & 26.583 \\
section) & & & & \\
\hline
\end{tabular}

$\mathrm{p}=.000)$ (Table 6). Had a single rater rated them two times, the intra-rater reliability would have been $.891(\mathrm{p}=.000)$.

\section{Construct Validity of the Posttest}

Factor analysis was run for the posttest as well.

It should be mentioned that the assumption of sampling adequacy was met. As displayed in Table 7 the KMO index of.812 was higher than the acceptable level of.50.

\section{Main study}

\section{The first question}

1. What is the effect of collaborative writing on Iranian EFL learners' task achievement in writing?

To answer the first research question, independent samples test was run. This could ensure that there is no difference between the groups. As can be seen in Table 8, the control group $(\mathrm{M}=57.41, \mathrm{SD}=3.11)$ had a slightly higher mean than the experimental group $(\mathrm{M}=57.62, \mathrm{SD}=2.93)$.

The results of the independent $\mathrm{t}$-test $(\mathrm{t}(40)=.411, \mathrm{p}=.628$, $\mathrm{r}=.718$ representing that two groups did not have a statistical significant di ference. (Table 9)

Next, an independent samples t-test was run to see if the female and male groups' mean scores

on the posttest are different. As observed in Table 10, the experimental group's mean score

$(\mathrm{M}=78.87, \mathrm{SD}=2.786)$ is close to the male group $(\mathrm{M}=59.75, \mathrm{SD}=2.952)$.

An independent samples t-test was run to find out if the difference between the control group and experimental group is significant. As displayed in Table 11. $(\mathrm{t}(40)=.241, \mathrm{p}=768$, $\mathrm{r}=$.748) shows that the groups mean scores are significantly different. As a result, the first null hypothesis was rejected

\section{Research Question 2}

2. What is the perception of Iranian EFL learners about implementing collaborative writing in classes?

For the second Research question, the participants in the experimental group $(n=20)$ were interviewed. All interviews were transcribes and analyzed thematically using NVIVO software. In the first question the participants were asked about the facilitating and inhibiting factors of collaborative writing.

Table 3. Test of normality, homogeneity test

\begin{tabular}{|c|c|c|c|c|c|}
\hline & \multirow{2}{*}{$\frac{\mathrm{N}}{\text { Statistic }}$} & \multicolumn{2}{|c|}{ Skewness } & \multicolumn{2}{|c|}{ Kurtosis } \\
\hline & & Statistic & Standard error & Statistic & Standard error \\
\hline Oxford placement test (Homogeneity test) & 60 & 0.414 & 0.114 & 0.226 & 0.494 \\
\hline
\end{tabular}

Table 4. Intra-class correlation coefficient; pretest of writing

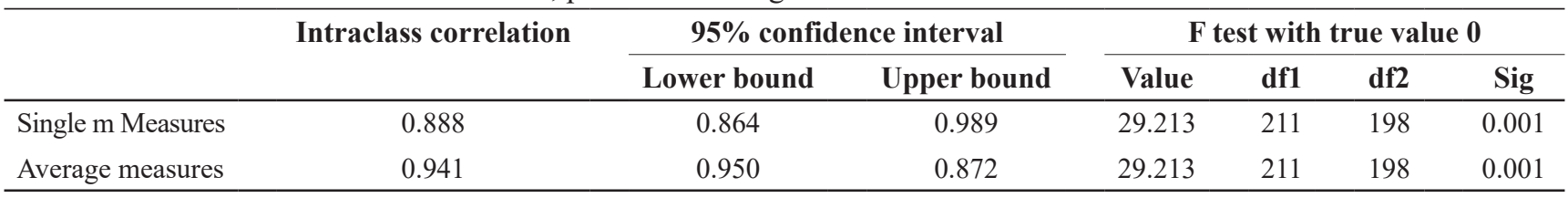


Table 5. Validity of the test

\begin{tabular}{lc} 
Kaiser-Meyer-Olkin measure of sampling adequacy & 0.811 \\
Bartlett's test of sphericity & 552.311 \\
Approx. Chi-square & 5 \\
Df & 0.000 \\
Sig. & 5 \\
\hline
\end{tabular}

Table 6. Intra-class correlation coefficient; posttest of writing

\begin{tabular}{lcccccccc}
\hline & Intraclass correlation & \multicolumn{2}{c}{$\mathbf{9 5 \%}$ confidence interval } & & \multicolumn{3}{c}{ F test with true value 0} \\
\cline { 3 - 4 } \cline { 6 - 8 } & & Lower bound & Upper bound & & Value & df1 & df2 & Sig \\
\hline Single measures & 0.891 & 0.864 & 0.9011 & & 29.123 & 147 & 198 & 0.001 \\
Average measures & 0.912 & 0.950 & 0.992 & & 29.123 & 147 & 198 & 0.001 \\
\hline
\end{tabular}

Table 7. KMO and Bartlett's test

\begin{tabular}{lc}
\hline Kaiser-Meyer-Olkin measure of sampling adequacy & 0.812 \\
Bartlett's test of sphericity & \\
Approx. Chi-square & 412.321 \\
Df & 9 \\
Sig. & 0.000 \\
\hline
\end{tabular}

Table 8. Descriptive statistics of the pretest

\begin{tabular}{lllcc}
\hline $\begin{array}{l}\text { Standard error } \\
\text { mean }\end{array}$ & Groups & N & Mean & $\begin{array}{c}\text { Standard } \\
\text { deviation }\end{array}$ \\
\hline Pretest & Control & 20 & 57.4167 & 3.1124 \\
& Experim & 20 & 57.6250 & 2.9312 \\
\hline
\end{tabular}

\section{Facilitating factors}

Most participants $(n=16)$ stated that they had a positive view about collaborative writing.

"Working in the group is fun... we help each other and, umm, laugh a lot."

Fifteen participants posited that they learn from their peer feedback. The reason, as stated by them, was that, feedback was received in practice when there was a need for it. One of the main issues stated by the participants was an in-depth look at the topic. Indeed, 14 participants asserted that each peer in the group looks at the topic from different angle. Then they have a variety of issues at their disposal to write.

"We were very selective, because, we had many things to write about."

Many participants also believed that they were really motivated to participate in the group activity because all group members were trying to improve the essay and they did not want to be left behind.

Some participants $(n=10)$ stated that writing in the group gave them the opportunity to use more vocabulary as they could utilize other peers' vocabulary knowledge.

Finally, 5 participants asserted that their writing habits were not as effective as other peers in the group. As a result, they adopted some of the habits by their friends and used them in their writing.

\section{Inhibiting Factors}

The main inhibiting factors seems to have been some peers' authority in the group. Eight participants' stated that they did not know how to select headlines from their outlines, as they could not come to a certain conclusion together. As a result, in some cases, the group's senior had decided what to write and in some other cases they had selected to write with disagreement. Although the occasion was rare, it had annoyed some of the peers in the groups.

The second inhibiting issue, as stated by 5 participants, was the authority of the teacher in the class. Some participants minded being observe very often by the teacher and preferred to have worked on their own.

"I feel stressed when the teacher walks around the class and checks my progress every 5 minutes."

Thus, it seems that the main problem with these participants has been the authority of the teacher and other peers in the group. Table 12 reveals a summary of both factors as perceived by the participants.

\section{DISCUSSION}

The results of this study indicated that collaborative writing can have significant effect on task achievement of EFL learners while writing. In addition it was revealed that students' perception is, in general, positive about collaborative writing.

Shin, Lidster and Sabraw (2016) believe that more research is required to understand how collaboration can affect language learners' writing. Indeed, one of the short comings in the literature was that they had dealt with writing accuracy and fluenc . To this end, this study looked at language learners' task achievement.

Congruent results were also reported by Zaffarani (2016) who concluded that collaborative writing can have positive effect on writing of EFL learners in terms of language production. Her study also revealed that teacher-selected pairs can outperform student-selected groups in terms of writing fluency and accurac .

Nassaji and Tian (2010), concluded that collaborative writing leads to more accurate use of phrasal verbs among the students. It seems that one of the reasons learners' task achievement in writing is improved (as stated by the partici- 
Table 9. Independent samples test

\begin{tabular}{|c|c|c|c|c|c|c|c|c|c|}
\hline & \multicolumn{2}{|c|}{$\begin{array}{l}\text { Levene's test } \\
\text { for equality of } \\
\text { variances } \\
\end{array}$} & \multicolumn{7}{|c|}{ t-test for equality of means } \\
\hline & \multirow[t]{2}{*}{$\mathbf{F}$} & \multirow[t]{2}{*}{ Sig } & \multirow[t]{2}{*}{$\mathbf{t}$} & \multirow[t]{2}{*}{ df } & \multirow[t]{2}{*}{ Sig (2-tailed) } & \multirow[t]{2}{*}{$\begin{array}{c}\text { Mean } \\
\text { difference }\end{array}$} & \multirow[t]{2}{*}{$\begin{array}{l}\text { Standard } \\
\text { error } \\
\text { difference }\end{array}$} & \multicolumn{2}{|c|}{$\begin{array}{l}95 \% \text { confidence } \\
\text { interval of the } \\
\text { difference }\end{array}$} \\
\hline & & & & & & & & Lower & Upper \\
\hline \multicolumn{10}{|l|}{ Male_female_pretest } \\
\hline $\begin{array}{l}\text { Equal variances } \\
\text { assumed }\end{array}$ & 0.027 & 0.651 & 0.411 & 40 & 0.21 & 0.2916 & 0.8334 & -1.38602 & 1.96935 \\
\hline $\begin{array}{l}\text { Equal variances not } \\
\text { assumed }\end{array}$ & & & 0.411 & 39.957 & 0.21 & 0.2916 & 0.8334 & -1.38606 & 1.96940 \\
\hline
\end{tabular}

Table 10. Descriptive statistics

\begin{tabular}{lllccr}
\hline & Group & N & Mean & Standard deviation & Standard error mean \\
\hline \multirow{2}{*}{ Posttest } & Control & 20 & 59.75 & 2.78681 & 0.56886 \\
& Experim & 20 & 78087 & 3.75645 & 0.65746 \\
\hline
\end{tabular}

Table 11. Independent samples test

\begin{tabular}{|c|c|c|c|c|c|c|c|c|c|}
\hline & \multicolumn{2}{|c|}{$\begin{array}{l}\text { Levene's test } \\
\text { for equality of } \\
\text { variances }\end{array}$} & \multicolumn{7}{|c|}{ t-test for equality of means } \\
\hline & \multirow[t]{2}{*}{$\mathbf{F}$} & \multirow[t]{2}{*}{ Sig } & \multirow[t]{2}{*}{$\mathbf{t}$} & \multirow[t]{2}{*}{ df } & \multirow[t]{2}{*}{$\begin{array}{c}\text { Sig } \\
\text { (2-tailed) }\end{array}$} & \multirow[t]{2}{*}{$\begin{array}{c}\text { Mean } \\
\text { difference }\end{array}$} & \multirow[t]{2}{*}{$\begin{array}{l}\text { Standard } \\
\text { error } \\
\text { difference }\end{array}$} & \multicolumn{2}{|c|}{$\begin{array}{l}95 \% \text { confidence } \\
\text { interval of the } \\
\text { difference }\end{array}$} \\
\hline & & & & & & & & Lower & Upper \\
\hline \multicolumn{10}{|l|}{ Male_female_posttest } \\
\hline $\begin{array}{l}\text { Equal variances } \\
\text { assumed }\end{array}$ & 0.164 & 0.587 & 0.241 & 40 & 19.12 & 0.12500 & 0.8287 & -1.5431 & 1.79318 \\
\hline $\begin{array}{l}\text { Equal variances not } \\
\text { assumed }\end{array}$ & & & 0.151 & 39.847 & 19.12 & 0.12500 & 0.82875 & -1.5433 & 1.79333 \\
\hline
\end{tabular}

Table 12. Inhibiting and facilitating factors of collaborative writing

\begin{tabular}{llllll}
\hline $\begin{array}{l}\text { Facilitating } \\
\text { factors }\end{array}$ & $\begin{array}{l}\text { Fun/motivating } \\
\text { atmosphere }\end{array}$ & $\begin{array}{l}\text { Receiving peer } \\
\text { corrective feedback }\end{array}$ & $\begin{array}{l}\text { Comprehensive view } \\
\text { over the topic }\end{array}$ & $\begin{array}{l}\text { Changing } \\
\text { bad habits }\end{array}$ & More vocabulary \\
\hline Inhibiting factors & Peers authority & Teacher's authority & & \\
\hline
\end{tabular}

pants) is having access to more vocabulary although the type of vocabulary was not mentioned by the participants.

Alshehadeh (2011) stated that students in collaborative writing groups outperform the individual writers in terms of on linguistic features such as content, organization, grammar and vocabulary. The results of students' survey in her study also revealed that students hold a better perception about collaborative writing than individual writing.

Storch and Wigglesworth (2010) designed a qualitative study to compare the effect of direct corrective feedback with indirect corrective feedback. While both types seemed to be effective, they found out that affective factors, although often ignored, affect uptake of information in case of corrective feedback. Indeed, one of the factors mentioned by the participants in this study was receiving feedback from peers in the class. The participants in this study found out that corrective feedback received from their peers can foster their writing quality. In this sense both studies are congruent.

In a qualitative study, Gordon (2008) investigated writing habits of two ESL students who were exceptionally good at writing. The results of this informal interview revealed that a) good writers are good readers, b) good writers attend to vocabulary, c) manage a degree of uncertainty, d) attend to meaning, e) attend to grammar, f) express ideas effectively and coherently and g) generate their own interest to write. In line with their study, the findings of the current study, as perceived by the learners, revealed that one of the issues that hampers language learners' writing is their habits which may not be effective. Having changed these habits in collaborative groups, they believed they had improved their writing skill. 


\section{CONCLUSION}

The results of this study showed that collaborative writing can have significant positive effect on task achievement of Iranian EFL learners. In addition to that, the EFL learners hold a positive view regarding collaborative writing in terms of motivation, peer feedback, comprehensive view over the topic, changing ineffective writing habits, and learning more vocabulary. Two issues seemed to bother the learners which were the authority of some peers in the group and the teacher. The findings of this study can be most useful to language teachers who aim at implementing collaborative writing tasks language classes. Reading this research report, they will know what some of the self-perceived challenges are collaborative writing are and what the benefits of this approach is compared to individual writing. Teacher trainers can also benefit from the findings of this study. As collaborative writing proved to have significant effect on task achievement of Iranian EFL learners, they can adopt the procedure used in this study and train language teachers to implement this mode of writing in their cases.

\section{REFERENCES}

Canale, M., and Swain, M., (1980). Theoretical basis of communicative approaches to second language teaching and testing. Applied Linguistics, 1, 1-47.

Choi, Y. H. (2016). Writing strategies in the process of L2 computer-mode academic writing with the use of multiple resources. English Teaching, 71, 3-28.

Connor, U., \& Mbaye, A. (2002). Discourse approaches to writing assessment. Annual Review of Applied Linguistics, 22, 263-278.

Creswell, J. W. (2009). Editorial: Mapping the field of mixed methods research. Journal of Mixed Methods Research, 3(2), 95-108.

Cusack, B., \& McCarter, S. (2007). Improve your IELTS: Listening and speaking skills. London: Macmillan Education.

Hedgcock, J., \& Lefkowitz, N. (1992). Collaborative oral/ aural revision in foreign language writing instruction. Journal of second language writing, 1(3), 255-276.

Hirvela, A. (1999). Collaborative writing instruction and communities of readers and writers. TESOL journal, 8(2), 7-12.

Kumaravadivelu, B. (2006). Understanding language teaching: From method to postmethod. Routledge: USA.

Larsen-Freeman, D., \& Anderson, M. (2013). Techniques and Principles in Language Teaching $3^{\text {rd }}$ edition. Oxford university press

Lozanov, G. (2004). Suggestology. Routledge: USA.

Lee, R. M., \& Kwan, C. Y. (1997). The use of problem-based learning in medical education. 醫學教育, 1(2), 11-20.
Mozaffari, S. H. (2016). Comparing student-selected and teacher-assigned pairs on collaborative writing. Language Teaching Research, 1362168816641703.

Nassaji, H., \& Tian, J. (2010). Collaborative and individual output tasks and their effects on learning English phrasal verbs. Language Teaching Research, 14(4), 397-419.

Riazi, A. M. (2016). Comparing writing performance in TOEFL-iBT and academic assignments: An exploration of textual features. Assessing Writing, 28, 15-27.

Gopee, N., \& Deane, M. (2013). Strategies for successful academic writing-Institutional and non-institutional support for students. Nurse education today, 33(12), $1624-1631$.

Gordon, L. (2008). Writing and good language learners. na. Jacobs, H., Zinkgraf, S. A., Wormuth, D. R., Hartfiel, V. F., \& Hughey, J. B. (1981). English Composition Program. Testing ESL Composition: a Practical Approach.

Rahimi, A., \& Qannadzadeh, J. A. (2010). Quantitative usage of logical connectors in Iranians' EFL Essay writing and logical and linguistic intelligences. Procedia-Social and Behavioral Sciences, 5, 2012-2019.

Savery, J. R. (2006). Overview of problem-based learning: Definitions and distinctions. Interdisciplinary Journal of Problem-based Learning, 1(1), 3.

Shehadeh, A. (2011). Effects and student perceptions of collaborative writing in L2. Journal of Second Language Writing, 20(4), 286-305.

Shin, S. Y., Lidster, R., Sabraw, S., \& Yeager, R. (2016). The effects of L2 proficiency differences in pairs on idea units in a collaborative text reconstruction task. Language Teaching Research, 20(3), 366-386.

Stevenson, M. (2016). A critical interpretative synthesis: The integration of Automated Writing Evaluation into classroom writing instruction. Computers and Composition, 42, 1-16.

Storch, N. (2005). Collaborative writing: Product, process, and students' reflections Journal of second language writing, 14(3), 153-173.

Storch, N., \& Wigglesworth, G. (2010). Learners' processing, uptake, and attention of corrective feedback on writing. Studies in Second Language Acquisition, 32(02), 303-334.

Strevens, M. (2009). Bigger than chaos: Understanding complexity through probability. Harvard University Press.

Verhelst, N., Van Avermaet, P., Takala, S., Figueras, N., \& North, B. (2009).Common European Framework of Reference for Languages: learning, teaching, assessment. Cambridge University Press.

Vygotsky, L.S. (1978) Mind in society Harvard University Press, Cambridge. 